\title{
Safety Performance pada Pekerja Berisiko Tinggi Ditinjau dari Kepribadian, Pengetahuan dan Motivasi Keselamatan Kerja
}

\author{
DEWI SYARIFAH \& ROSATYANI PUSPITA ADIATI \\ Departemen Psikologi Industri dan Organisasi, Fakultas Psikologi Universitas Airlangga
}

\begin{abstract}
ABSTRAK
Safety performance merupakan perilaku kerja yang terkait dengan keselamatan pekerja dalam melakukan pekerjaannya. Banyaknya kasus kecelakaan kerja yang terjadi di Indonesia menguatkan urgensi dilakukannya penelitian ini. Penelitian ini bertujuan untuk mengetahui faktor-faktor yang mempengaruhi safety performance seseorang dalam bekerja. Skala untuk mengukur kepribadian, pengetahuan dan motivasi seseorang tentang keselamatan kerja, serta safety performance diberikan kepada 142 pekerja dengan risiko tinggi. Analisis regresi menunjukkan bahwa ada korelasi negatif yang signifikan dari tipe kepribadian neuroticism $(B=-0.067, S E=0.031$, nilai $\mathrm{p}=.03)$, dan korelasi positif dari safety knowledge $(B=0.387, S E=0.06$, nilai $\mathrm{p}<.001)$ dan safety motivation $(B=0.317, S E=0.064$, nilai $\mathrm{p}<.001)$ terhadap aspek compliance pada safety performance. Lebih lanjut, ada korelasi negatif yang signifikan dari pendidikan $(B=-0.406, S E=0.160$, nilai $\mathrm{p}=.012)$, serta korelasi positif dari aspek kepribadian openness to experience $(B=0.082, S E=0.03$, nilai $\mathrm{p}=.008)$, safety knowledge $(B=0.355$, $S E=0.068$, nilai $\mathrm{p}<.001)$ dan safety motivation $(B=0.454, S E=0.073$, nilai $\mathrm{p}<.001)$ terhadap aspek partisipasi. Hasil penelitian ini dapat dijadikan dasar seleksi maupun pengembangan karyawan, khususnya untuk mereka yang bekerja pada lingkungan dengan resiko tinggi.
\end{abstract}

Kata kunci: kepribadian Big Five, safety knowledge, safety motivation, safety performance

\begin{abstract}
Safety performance is a model of individual behavior in the workplace, which is related to how they perform job safely. The data of accidents at work recorded in Indonesia underlied the importance of this study, which aimed to examine the factors that affect individual safety performance in work. The scale for measuring personality, knowledge and motivation in safety performance, as well as safety performance is given to 142 high-risk workers. The result of regression analysis showed that there was a significant negative correlation of neuroticism personality $(B=-0.067, S E=0.031, \mathrm{p}$ value $=.03)$, and positive correlation of safety knowledge $(B=0.387, S E=0.06$, p value $<.001)$, and safety motivation $(B=0.317, S E=0.064$, p value $<.001)$ on compliance behavior of safety performance. Furthermore, there was a significant negative correlation of education $(B=-0.406, S E=0.160$, p value $=.012)$, as well as the positive correlation of openness to experience $(B=0.082, S E=0.03, \mathrm{p}$ value $=.008)$, safety knowledge $(B=0.355, S E=0.068, \mathrm{p}$ value $<.001)$ and safety motivation $(B=0.454, S E=0.073, \mathrm{p}$ value $<.001)$ on participation behavior of safety performance. This finding can be considered as the basis for selection and development of employees, especially for those who applied for a high risk job.
\end{abstract}

Key words: big five personality, safety knowledge, safety motivation, safety performance 
INSAN Jurnal Psikologi dan Kesehatan Mental, 2018, Vol. 3(1), 23-30, doi: 10.20473/jpkm.v3i12018.23-30 Dikirimkan: 22 Oktober 2018 Diterima: 31 Oktober 2018 Diterbitkan: 4 November 2018 Editor: Rizqy Amelia Zein

*Alamat korespondensi: Fakultas Psikologi Universitas Airlangga, Jl. Airlangga 4 -6 Surabaya. Pos-el: dewi.syarifah@psikologi.unair.ac.id

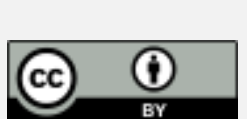

Naskah ini merupakan naskah dengan akses terbuka dibawah ketentuan the Creative Common Attribution License (http://creativecommons.org/licenses/by/4.0), sehingga penggunaan, distribusi, reproduksi dalam media apapun atas artikel ini tidak dibatasi, selama sumber aslinya disitir dengan baik.

\section{P E N D A H U L U A N}

Isu tentang kecelakaan kerja pada tahun-tahun terakhir ini banyak menarik perhatian, karena sangat mempengaruhi produktivitas kerja. Kecelakaan kerja menimbulkan kerugian bagi berbagai pihak, baik perusahaan, pekerja, maupun keluarga pekerja. Per Februari 2018, ada 12 kecelakaan konstruksi selama tujuh bulan terakhir. Adapun sepanjang 2017, Badan Penyelenggara Jaminan Sosial (BPJS) Ketenagakerjaan melansir ada 1.877 klaim kecelakaan kerja konstruksi dengan nilai setara Rp41,2 miliar (Widyastuti, 2018).

Bukan hanya pekerja di bidang konstruksi, isu mengenai keselamatan kerja di bidang lain seperti kesehatan dan industri juga perlu mendapatkan perhatian. Adanya resiko penularan penyakit juga mengancam pekerja di bidang kesehatan dan industri kimia ditunjukkan dengan munculnya kasus mengenai dokter gigi yang tertular HIV/AIDS (Listyanti, 2013) dan berita meledaknya tangki kimia jenis hydrochloric acid $(\mathrm{HCl})$ milik perusahaan kimia Kampung Pengoreng, Desa Sumuranja, Kecamatan Pulau Ampel, Kabupaten Serang, Banten (Ulum, 2010) yang menyebabkan satu orang pekerja tewas dan empat orang lainya luka berat.

Data-data tersebut menunjukkan bahwa kecelakaan kerja bisa terjadi dimanapun, terutama pada jenis pekerjaan dengan resiko tinggi, yaitu pekerjaan yang rentan terhadap berbagai faktor yang membahayakan keselamatan atau kesehatan pekerja, seperti pekerjaan di bidang konstruksi, rumah sakit, laboratorium maupun industri kimia.

Pemerintah telah menunjukkan kepedulian dan tanggung jawabnya untuk mencegah semakin banyaknya kecelakaan kerja, diantaranya dengan menerbitkan UU No. 1 Tahun 1970 tentang Keselamatan Kerja, yang mewajibkan kepada perusahaan untuk melaksanakan syarat-syarat keselamatan kerja serta melakukan pembinaan dan penjelasan kepada tenaga kerjanya tentang syaratsyarat tersebut. Selain itu, Peraturan Pemerintah No. 50 Tahun 2012 tentang Penerapan Sistem Manajemen Keselamatan dan Kesehatan Kerja (SMK3), mewajibkan setiap perusahaan yang mempekerjakan pekerja atau buruh minimal 100 orang untuk menerapkan SMK3. Namun pada kenyataannya, angka kecelakaan kerja bukannya mengalami penurunan, justru mengalami kenaikan.

Data-data kecelakaan kerja di atas menunjukkan bahwa program keselamatan dan kesehatan kerja di Indonesia belum bisa dikatakan berhasil. Keberhasilan pelaksanaan keselamatan dan kesehatan kerja membutuhkan peran dari berbagai pihak, diantaranya peran organisasi, pemerintah dan tenaga kerja. Peran organisasi dapat berupa upaya organisasi untuk menciptakan iklim organisasi yang positif, sedangkan peran pemerintah berupa kebijakan dan peraturan yang disusun untuk mendukung keselamatan dan kesehatan kerja.

Peran tenaga kerja juga sangat dibutuhkan untuk mendukung keberhasilan pelaksanaan keselamatan dan keberhasilan kerja, yaitu dengan menampilkan safety performance. Safety performance adalah suatu

INSAN Jurnal Psikologi dan Kesehatan Mental

2018, Vol. 3(1), 23-30

doi: 10.20473/jpkm.v3i12018.23-30 
model perilaku keamanan kerja dari Neal dan Griffin (1997 dalam Neal, dkk., 2000) yang mendasarkan pada teori kinerja (job performance) (Borman \& Motowidlo, 1993; Campbell, dkk., 1993 dalam Neal, dkk., 2000). Brand (2010) menyatakan bahwa komponen performance menunjukkan dimensi-dimensi besar dari perilaku yang relevan dengan tugas yang diberikan. Model ini menggabungkan dua dimensi dari safety performance yaitu kepatuhan dan partisipasi. Kepatuhan merupakan keterlibatan dan kelekatan pada prosedur keselamatan dan melaksanakan pekerjaan dalam cara yang aman, mempersiapkan dan menggunakan peralatan pengamanan yang tepat dalam bekerja.

Lebih lanjut, partisipasi merupakan perilaku keterlibatan yang tidak langsung berhubungan dengan keselamatan individu, namun mendukung terwujudnya lingkungan yang aman, seperti misalnya menolong rekan kerja, meningkatkan program keselamatan dalam lingkungan kerja, menunjukkan inisiatif, dan memberikan usaha meningkatkan keselamatan kerja dalam lingkungan pekerjaan, maupun hadir dalam pertemuan-pertemuan yang membahas keselamatan kerja.

Pada level individu, perilaku kerja aman dipengaruhi oleh karakteristik-karakteristik individu seperti pendidikan, gender, dan usia (Salminen, dkk., 2013). Penelitian dari Hogan dan Foster (2013) juga menyatakan bahwa faktor kepribadian seperti conscientiousness, extraversion, neuroticism, openness, agreableness individu juga mempengaruhi perilaku keamanan kerja. Karakteristik individu lainnya seperti gender, usia dan pendidikan juga dipertimbangkan sebagai hal yang mempengaruhi perilaku keamanan kerja.

Berdasarkan hal tersebut, penelitian ini bertujuan untuk melihat apakah faktor-faktor kepribadian (extraversion, agreeableness, conscientiousness, neuroticism, openness to experience), pengetahuan tentang keselamatan kerja, motivasi keselamatan kerja dan variabel demografis lainnya (usia, gender, pendidikan dan pengalaman) memiliki pengaruh terhadap perilaku keselamatan kerja.

Penelitian ini penting untuk dilakukan karena melihat kondisi terkini telah banyak usaha yang dilakukan untuk meningkatkan keselamatan dan kesehatan kerja namun fakta yang ada masih banyak kecelakaan kerja yang terjadi. Penelitian ini diharapkan dapat memberikan gambaran mengenai karakteristik personal yang memiliki dampak terhadap perilaku keamanan kerja, sehingga dapat dijadikan dasar pengembangan personal terhadap pegawai yang diharapkan dapat menunjukkan perilaku keamanan kerja.

\section{E T O D E}

\section{Desain Penelitian}

Pendekatan yang digunakan dalam penelitian ini adalah kuantitatif untuk dengan desain penelitian survei cross-sectional. Data dikumpulkan dengan menggunakan instrumen berupa skala psikologis. Sebelum menyatakan berpartisipasi, partisipan penelitian diminta untuk menyetujui informed consent secara lisan.

\section{Partisipan}

Partisipan pada penelitian ini adalah para pekerja yang bekerja di tiga organisasi yang masing-masing mewakili lingkungan kerja yang beresiko tinggi, yaitu organisasi yang bergerak di bidang bahan kimia, medis dan jasa konstruksi. Jumlah partisipan sebanyak 142 orang, yaitu para pekerja di tiga perusahaan kimia (62 orang), rumah sakit (22 orang) dan perusahaan jasa konstruksi (58 orang). Partisipan lakilaki berjumlah 116 orang dan perempuan berjumlah 26 orang. 
Berdasarkan tingkat pendidikan, 5 orang berpendidikan SMP, 89 orang berpendidikan SMA, 37 orang berpendidikan D3-S1, 10 orang berpendidikan S2 dan 1 orang berpendidikan S3. Berdasarkan masa kerja partisipan, diketahui 37 orang memiliki masa kerja kurang dari 2 tahun, 33 orang memiliki masa kerja 2-5 tahun, 16 orang memiliki masa kerja 5-7 tahun, 7 orang memiliki masa kerja 7-10 tahun, dan 49 orang memiliki masa kerja lebih dari 10 tahun. Sebelum mengisi kuesioner, partisipan ditanyakan tentang kesediaannya terlebih dahulu untuk terlibat dalam penelitian ini.

\section{Pengukuran}

Alat ukur yang digunakan dalam penelitian ini terdiri dari kuisioner yang berisikan identitas dan data demografis (pendidikan, usia, jenis kelamin dan pengalaman kerja) serta empat skala likert yang masing-masing mengukur kepribadian, pengetahuan mengenai keselamatan kerja, motivasi keselamatan kerja dan perilaku keselamatan kerja. Kepribadian pada penelitian ini diukur melalui penjumlahan skor pada skala pengukuran kepribadian (extraversion, agreeableness, conscientiousness, neuroticism, dan openness to experience), yang terdiri dari 44 aitem, dengan pilihan respon 1 hingga 5. Respon 1 artinya "sangat tidak sesuai", respon 2 artinya "tidak sesuai", respon 3 artinya "ragu-ragu", respon 4 artinya "sesuai", dan respon 5 artinya "sangat sesuai". Skala kepribadian yang digunakan diadaptasi dari BIF (Big Five Inventory) oleh John dan Srivastava (1999).

Pengetahuan dan motivasi keselamatan kerja diukur melalui penjumlahan skor pada skala pengetahuan tentang keselamatan kerja (safety knowledge) yang terdiri dari 4 aitem dan skala motivasi keselamatan kerja (safety motivation) yang terdiri dari 4 aitem, yang diadaptasi dari penelitian Neal, dkk. (2000). Perilaku keselamatan kerja diukur melalui penjumlahan skor skala perilaku keselamatan kerja (safety performance) dari Neal, dkk. (2000), yang terdiri dari 7 aitem. Keempat skala tersebut memiliki pilihan respon yang rentangnya 1 hingga 5. Respon 1 artinya "sangat tidak sesuai", respon 2 artinya "tidak sesuai", respon 3 artinya "ragu-ragu", respon 4 artinya "sesuai", dan respon 5 artinya "sangat sesuai". Semakin tinggi skor menunjukkan dukungan yang semakin besar pada variabel yang diukur.

Reliabilitas alat ukur pada penelitian ini cukup bervariasi, yang ditunjukkan melalui nilai Cronbach's alpha dari 0.534-0.814. Reliabilitas skala extraversion adalah 0.601, skala agreeableness sebesar 0.534, skala conscientiousness sebesar 0.781 , skala neuroticism sebesar 0.744 , skala openness to experience sebesar 0.717 , skala safety knowledge sebesar 0.678 , skala safety motivation sebesar 0.814 , skala kepatuhan sebesar 0.716 dan skala partisipasi sebesar 0.732 .

\section{Analisis Data}

Analisis data yang digunakan antara lain dengan menggunakan analisis regresi. Analisis regresi adalah upaya untuk menjelaskan kontribusi variabel prediktor terhadap variabel tergantung. Dalam penelitian ini, variabel bebas terdiri dari beberapa variabel, sehingga teknik analisis yang digunakan adalah analisis regresi berganda. Analisis data pada penelitian ini menggunakan software SPSS (Statistical Package for Social Sciences) versi 20.0 .

\section{HAS IL PENELIT IAN}

\section{Mengidentifikasi determinan kepatuhan}

Hasil penelitian menunjukkan model regresi cenderung good fit $(\mathrm{F}(10,141)=20.189$, nilai $\mathrm{p}<.001$, $\mathrm{R}^{2}=.609$ ). Proporsi varians dari social loafing yang dijelaskan oleh semua prediktor dalam penelitian ini 
adalah sebesar 60.9\%, sedangkan sisanya dipengaruhi oleh variabel lain yang tidak diukur dalam penelitian ini.

Tabel 1. Parameter Prediktor dalam Model Regresi ( $\mathrm{N}=142)$

\begin{tabular}{lcccccc}
\hline \multicolumn{1}{c}{ Prediktor } & B & SE & $\boldsymbol{\beta}$ & t & nilai p & VIF \\
\hline Extraversion & -0.033 & 0.044 & -0.047 & -0.746 & .457 & 1.426 \\
Agreeableness & -0.022 & 0.040 & -0.033 & -0.551 & .582 & 1.266 \\
Conscientiousness & 0.017 & 0.026 & 0.050 & 0.649 & .518 & 2.115 \\
Neuroticism & -0.067 & 0.031 & -0.136 & -2.193 & $.030^{*}$ & 1.392 \\
Openness & 0.012 & 0.027 & 0.028 & 0.438 & .662 & 1.498 \\
Knowledge & 0.387 & 0.060 & 0.453 & 6.431 & $.000^{*}$ & 1.784 \\
Motivation & 0.317 & 0.064 & 0.339 & 4.928 & $.000^{*}$ & 1.707 \\
Jenis Kelamin & 0.103 & 0.258 & 0.027 & 0.398 & .691 & 1.606 \\
Pendidikan & -0.249 & 0.141 & -0.116 & -1.767 & .080 & 1.565 \\
Masa Kerja & 0.007 & 0.054 & 0.008 & 0.133 & .895 & 1.284 \\
Konstanta & 2.018 & 1.490 & & 1.354 & .178 & \\
\hline
\end{tabular}

*nilai $\mathrm{p}<.05$

Berdasarkan tabel di atas, menunjukkan bahwa ada korelasi yang negatif antara neuroticism terhadap kepatuhan $(B=-0.067, S E=0.031$, nilai $\mathrm{p}=.03)$, dan korelasi positif dari safety knowledge $(B=0.387$, $S E=0.06$, nilai $\mathrm{p}<.001)$, dan safety motivation $(B=0.317, S E=0.064$, nilai $\mathrm{p}<.001)$ terhadap aspek kepatuhan pada safety performance.

\section{Mengidentifikasi determinan partisipasi}

Hasil analisis regresi menunjukkan model regresi cenderung good fit $(\mathrm{F}(10,141)=29.132$, nilai $\mathrm{p}<.001$, $\mathrm{R}^{2}=.641$ ). Proporsi varians dari social loafing yang dijelaskan oleh semua prediktor dalam penelitian ini adalah sebesar $64.1 \%$, sedangkan sisanya dipengaruhi oleh variabel lain yang tidak diukur dalam penelitian ini.

Tabel 2. Parameter Prediktor dalam Model Regresi (N=142)

\begin{tabular}{lcccccc}
\hline \multicolumn{1}{c}{ Prediktor } & B & SE & $\boldsymbol{\beta}$ & t & nilai p & VIF \\
\hline Extraversion & 0.030 & 0.050 & 0.037 & 0.608 & .544 & 1.426 \\
Agreeableness & -0.055 & 0.046 & -0.068 & -1.190 & .236 & 1.266 \\
Conscientiousness & 0.018 & 0.030 & 0.044 & 0.605 & .546 & 2.115 \\
Neuroticism & -0.041 & 0.035 & -0.070 & -1.182 & .239 & 1.392 \\
Openness & 0.082 & 0.030 & 0.167 & 2.700 & $.008^{*}$ & 1.498 \\
Knowledge & 0.355 & 0.068 & 0.350 & 5.187 & $.000^{*}$ & 1.784 \\
Motivation & 0.454 & 0.073 & 0.411 & 6.226 & $.000^{*}$ & 1.707 \\
Jenis Kelamin & 0.372 & 0.293 & 0.081 & 1.269 & .207 & 1.606 \\
Pendidikan & -0.406 & 0.160 & -0.161 & -2.547 & $.012^{*}$ & 1.565 \\
Masa Kerja & 0.010 & 0.062 & 0.009 & 0.164 & .870 & 1.284 \\
Konstanta & 2.162 & 1.691 & & 1.278 & .203 & \\
\hline
\end{tabular}

*nilai $\mathrm{p}<.05$ 
Berdasarkan tabel koefisien regresi diatas, ada korelasi negatif yang signifikan dari pendidikan $(B=-$ $0.406, S E=0.160$, nilai $\mathrm{p}=.012$ ), serta korelasi positif dari aspek kepribadian openness to experience $(B=0.082$, $S E=0.03$, nilai $\mathrm{p}=.008)$, safety knowledge $(B=0.355, S E=0.068$, nilai $\mathrm{p}<.001)$ dan safety motivation $(B=0.454, S E=0.073$, nilai $\mathrm{p}<.001)$ terhadap aspek partisipasi.

\section{I S K U S I}

Hasil penelitian di atas memberikan wacana baru mengenai pengaruh kepribadian terhadap perilaku keselamatan kerja. Berdasarkan analisis data hasil penelitian di atas, dapat dilihat bahwa aspek kepribadian neuroticism, pengetahuan dan motivasi berperilaku keselamatan kerja memiliki korelasi signifikan terhadap perilaku kepatuhan dalam keselamatan kerja. Aspek ini berkaitan dengan perilaku patuh dan konsistensi seseorang dalam melaksanakan tugas dan prosedur keselamatan kerja yang ada di lingkungannya. Aspek kepribadian yang memiliki pengaruh terhadap perilaku keselamatan kerja adalah neuroticism, dimana hasil penelitian ini menunjukkan bahwa individu yang memiliki tingkat neuroticism lebih tinggi cenderung akan menunjukkan perilaku kepatuhan (kepatuhan) dalam menjamin keselamatan kerja yang rendah.

Neuroticism yang merupakan tendensi umum dari seseorang untuk merasakan afeksi negatif seperti ketakutan, kesedihan, kemarahan, kecemasan, rasa bersalah, dan kesulitan untuk mengatasi stress akan menyebabkan seseorang cenderung kurang mampu menunjukkan perilaku patuh dan mematuhi prosedur untuk menghasilkan safety performance. Hasil penelitian ini senada dengan penelitian dari Seibokatie dan Endriulaitiene (2012), yang menyatakan bahwa neuroticism yang rendah memiliki hubungan dengan tingginya perilaku menghindari resiko pada orang-orang yang berprofesi pengemudi. Individu yang memiliki tingkat neuroticism yang tinggi memiliki kemudahan untuk mengalami stress dan mudah tertekan, yang membuat mereka cenderung kurang mampu mempertahankan fokus bekerja termasuk ketika mereka harus melaksanakan prosedur standar ketika berada dalam situasi yang beresiko.

Hasil penelitian ini juga menunjukkan bahwa semakin tinggi pengetahuan dan motivasi seseorang dalam berperilaku aman, maka akan semakin tinggi pula perilaku kepatuhan mereka, yang ditunjukkan melalui kepatuhan mereka dalam melaksanakan prosedur kerja yang aman. Individu yang memiliki pemahaman mengenai keselamatan kerja serta memiliki keinginan, akan mampu mematuhi aturan dan melaksanakan prosedur kerja yang menjamin keselamatan mereka dalam melakukan tugas dalam unit kerjanya.

Selanjutnya, hasil penelitian ini juga menunjukkan bahwa aspek kepribadian openness to experience, pengetahuan dan motivasi berperilaku aman dalam bekerja, memiliki pengaruh positif terhadap perilaku keselamatan kerja pada aspek partisipasi. Kepribadian openness to experience yang merupakan kecenderungan seseorang untuk bersikap orisinal, terbuka, memiliki ketertarikan dengan banyak hal, serta keingintahuan yang besar akan semakin meningkatkan perilaku partisipasi seseorang, yang merupakan upaya tidak langsung untuk meningkatkan potensi perilaku keselamatan kerja di lingkungannya. Kepribadian openness to experience yang dimiliki seseorang, membuatnya aktif mencari cara-cara baru untuk memastikan tujuan organisasi tercapai, salah satunya di bidang keselamatan kerja.

Mereka yang memiliki tipe kepribadian openness to experience yang tinggi, memiliki tendensi untuk memunculkan perilaku menolong rekan kerja, meningkatkan program keselamatan dalam lingkungan kerja, menunjukkan inisiatif, dan memberikan usaha meningkatkan keselamatan kerja dalam lingkungan pekerjaan yang lebih tinggi pula. Penjelasan ini sejalan dengan penelitian Hogan dan Foster (2013) yang menunjukkan bahwa kepribadian openness to experience memiliki pengaruh positif terhadap safety performance ditempat kerja, khususnya kepada aspek trainable, yaitu dorongan dan 
keinginan seseorang untuk mendapatkan pengetahuan baru mengenai keselamatan kerja, serta mengaplikasikan pelatihan di bidang keselamatan kerja untuk meningkatkan performance organisasi dalam bidang keselamatan kerja.

Demikian pula bahwa semakin tinggi pengetahuan dan motivasi seseorang tentang keselamatan kerja, maka akan semakin tinggi pula perilaku partisipasi mereka, yang ditunjukkan melalui keaktifan mereka dalam mewujudkan lingkungan kerja yang aman, melalui perilaku-perilaku seperti menolong rekan kerja maupun membuat program yang bisa meningkatkan keselamatan kerja. Yang perlu dicermati dari hasil penelitian ini adalah bahwa tingkat pendidikan memiliki pengaruh negatif terhadap perilaku partisipasi, yang artinya menunjukkan bahwa semakin tinggi pendidikan seseorang, justru akan menurunkan tingkat partisipasi dalam safety performance yang dia miliki. Akan tetapi, dengan melihat proporsi partisipan yang sebagian besar memiliki pendidikan pada jenjang SMA dan S1, maka hal ini perlu ditelaah lebih lanjut melalui pembuktian pada penelitian-penelitian selanjutnya.

\section{S I M P U L A N}

Hasil penelitian menunjukkan bahwa terdapat pengaruh negatif neuroticism terhadap kepatuhan dan terdapat korelasi positif antara safety knowledge dan safety motivation terhadap kepatuhan. Selain itu, ditemukan terdapat pengaruh negatif pendidikan terhadap partisipasi dan terdapat pengaruh positif openness to experience, safety motivation dan safety knowledge tehadap partisipasi.

Hasil penelitian ini dapat digunakan sebagai dasar pertimbangan dalam melakukan aktivitas seleksi maupun rotasi karyawan, khususnya untuk organisasi yang memiliki kebutuhan tenaga kerja dalam lingkungan yang beresiko. Hasil dari penelitian ini perlu diperdalam, terutama berkaitan dengan jumlah subyek pada tiap kelompok jenjang pendidikan yang tidak berimbang. Studi lebih lanjut akan membantu dalam menjelaskan pengaruh pendidikan terhadap perilaku safety performance.

\section{PUSTAKA ACUAN}

Borman, W. C., \& Motowidlo, S. M. (1993). Expanding the criterion domain to include elements of contextual performance. Personnel Selection in Organizations; San Francisco: Jossey-Bass, 71.

Brand, L. M. (2010). Exploring a model of psychological fitness for work: are individual difference variables relevant in a model of safety performance? (Doctoral dissertation, James Cook University).

Hogan, J., \& Foster, J. (2013). Multifaceted personality predictors of workplace safety performance: More than conscientiousness. Human Performance, 26(1), 20-43.

John, O. P., \& Srivastava, S. (1999). The Big Five trait taxonomy: History, measurement, and theoretical perspectives. Handbook of personality: Theory and research, 2(1999), 102-138.

Listyanti, A.S. (2013). 3 Dokter Gigi Tertular Pasien Pengidap AIDS. Tempo.Co. Diakses dari http://www.tempo.co/read/news/2013/03/05/173465143/3-Dokter-Gigi-Tertular-PasienPengidap-AIDS.

Millon, T., Lerner, M. J., \& Weiner, I. B. (2003). Handbook of Psychology: Volume 5, Personality and Social Psychology. New Jersey: John Wiley \& Sons, Inc.

Neal, A., Griffin, M. A., \& Hart, P. M. (2000). The impact of organizational climate on safety climate and individual behavior. Safety science, 34(1-3), 99-109.

Peraturan Pemerintah No. 50 Tahun 2012 tentang Penerapan Sistem Manajemen Keselamatan dan Kesehatan Kerja (SMK3).

INSAN Jurnal Psikologi dan Kesehatan Mental

2018, Vol. 3(1), 23-30

doi: 10.20473/jpkm.v3i12018.23-30 
Salminen, S., Gyekye, S. A., \& Ojajarvi, A. (2013). Individual and organizational factors of safe behaviour among Ghanaian industrial workers. Engineering Management Research, 2(1), 98.

Seibokaite, L., \& Endriulaitiene, A. (2012). The role of personality traits, work motivation and organizational safety climate in risky occupational performance of professional drivers. Baltic Journal of Management, 7(1), 103-118.

Ulum, W. (2010). Tangki Kimia Meledak, Satu Orang Tewas dan Empat Terluka. Tempo.Co. Diakses dari https://nasional.tempo.co/read/262210/tangki-kimia-meledak-satu-orang-tewas-dan-empatterluka/full\&view=ok.

UU No. 1 Tahun 1970 tentang Keselamatan Kerja.

Widyastuti, A.Y. (2018). Marak Kecelakaan Kerja, PU Genjot Sertifikasi Ahli K3. Tempo.Co. Diakses dari https://bisnis.tempo.co/read/1110475/marak-kecelakaan-kerja-pu-genjot-sertifikasi-ahli$\underline{\mathrm{k} 3 / \text { full\&view }=\mathrm{ok}}$. 